American Journal of Environmental Sciences 7 (5): 448-455, 2011

ISSN 1553-345X

(C) 2011 Science Publications

\title{
Has The Sea Changed? Qualitative Analyses on the Views of Fishermen in the east coast zone of Peninsular
}

\author{
Hayrol Azril Mohamed Shaffril, Bahaman Abu Samah, \\ Jeffrey Lawrence D'Silva and Jegak Uli \\ Laboratory of Sustainable Development and Agriculture Extension, \\ Institute for Social Science Studies, Universiti Putra Malaysia, \\ Putra Infoport, 43400 Serdang, Selangor Darul Ehsan, Malaysia
}

\begin{abstract}
Problem statement: Pressure from the uncontrolled human activities had caused damages to our environment. The sea, as one of the environment components has also suffered from these activities. Fishermen, whom depend on the sea for their income and sources of protein, can be one of the groups who are suffering the most. This study intends to discover the perception of this group on the current situation of the sea, their perception on the quantity and the quality of the sea fauna, their perception on the possible factors that contribute to these changes and impacts of these changes on their socio-economic activities. Approach: This was a qualitative study whereby four in-depth interviews were conducted with the fishermen of the east coast zone of Peninsular Malaysia whom their main fishing area was on South China Sea. The data then were transcribed verbatim and analyzed. Results: Data gained had proven that the fishermen agreed that the current situation on the South China Sea was not anymore similar to their early day as a fisherman. The weather nowadays was difficult to be predicted as there are changes in the trend of sea current, waves and temperature. They also agreed that the quality and quantity of the flora and fauna in their catching areas were lesser compared to the past. There are number of possibilities that can contribute to these changes which were illegal bottom trawling, foreign fishermen intrusion, climate change and fishing pressure. All of these according to them were affecting their socio-economic activities. Conclusion/Recommendation: Based on the data gained, it is recommended that more monitoring programs can be conducted to reduced illegal bottom trawling activities; Program such as Rakan Cop which is introduced by Royal Police of Malaysia can be practiced among the concern agencies and fishermen. A number of programs to increase awareness among the fishermen on the danger of illegal bottom trawling activities, threats of the climate change and the importance for them to save usage of energy (eg: Fuel) can also be conducted. Some effective actions taken by other countries to overcome their fishing pressure might also have the potential to be practiced in Malaysia.
\end{abstract}

Key words: Environment, socio-economic activities, east coast zone, fishermen, sea changes

\section{INTRODUCTION}

There is a number of issues that are frequently related to agriculture such as gender (Shaffril et al., 2010), youth involvement (D'Silva et al., 2010 and Uli et al., 2010) and sustainable agriculture (D'Silva et al., 2011). Unlike the agriculture industry, the fisheries industries are more affected by the negative impacts of the current climate and human activities in which brings threats to their socio-economic aspects (Mia, et al., 2011; Fuller and Harhay, 2010; Hamdi et al., 2009). Not only people become the victims of this change, the sea also has suffered from it (Rashid et al., 2011). As been studied widely, it was found that human activities are among the major contributor for this change. Activities such as overuse of fuel consumption, fishing pressure and bottom trawling are among the identified causes. If actions to overcome all of these not to be taken earlier, inevitably, the next generation would suffer. Not to forget, group who largely depend on the sea for their sources of income and protein; the fishermen. Certainly, they also would suffer the most. Generally, this study would like to discover the perception of the east coast zone fishermen in Peninsular Malaysia on the current situation of the South China Sea. On top of it, this study intends to

Corresponding Author: Hayrol Azril Mohamed Shaffril, Laboratory of Sustainable Development and Agriculture Extension, Institute for Social Science Studies, Universiti Putra Malaysia, Putra Infoport, 43400 Serdang, Selangor Darul Ehsan, Malaysia Tel: 603-89471870 Fax: 603-89471856 
Am. J. Environ. Sci., 7 (5): 448-455, 2011

discuss their perception on any changes that have occurred to the quality and quantity of South China Sea fauna, the possible factors that contributes to these changes and whether these changes have affected their socio-economic activities Table 1.

Fisheries industry and fishermen in Malaysia: Before moving on to the main objective, it is better to get a clearer picture of the fisheries industry and fishermen in Malaysia. This study has put a specific focus on the east coast zone, a zone in Peninsular Malaysia that is highly related to fisheries activities. There are four states located at the east coast zone of Peninsular Malaysia namely Kelantan, Terengganu, Pahang and Johor (East). These four states consist of 17 fisheries districts as illustrated in Table 2. South China Sea has offered huge sources of income and protein for fishermen and the community. Doubtlessly, it continues to play its important role in providing persistent food supplies for the country.

Productivity of the east coast zone fishermen in Peninsular Malaysia: Figure 1 depicts the total of marine fish landed in the period of five years 20052009. It can be seen that productivity of the east coast zone fishermen in Peninsular Malaysia continue to provide a persistent food supplies to the Malaysians. It can be demostrated that fishermen in this zone are able to provide a consistent food supplies in the period of five years, whereby each year they were able to land more than 30,000 tonnes. The highest number of marine fish landed in the period of 2005-2009 was recorded in 2006 which is (386,263 tonnes) while the lowest was recorded in 2005 which is $(318,642)$.

Table 3 and Fig. 2 indicate the number of registered fishermen in the east coast zone of Peninsular Malaysia. As beeb depictedm there are 32565 registered fishermen can be found at the east coast zone in Malaysia. Terengganu is the state with the highest number of registered fishermen which is 10421, while Bachok and Pasir Puteh is district with the highest number of registered fishermen which is 6430. However, not too many registered fishermen can be found at the district of Setiu. The total number of registered fishermen in the east coast zone of Peninsular Malaysia indicates that there a larger number of people depend on the sea for getting their income and protein. The fact stated here raise concerns among us on what will happens if they are not able to go to the sea again due to the impacts of the global warming and are they already experienced the impact of global warming? These issues will be discussed in the next part of this study.
Table 1: Respondents background

\begin{tabular}{|c|c|c|c|c|}
\hline & & $\begin{array}{l}\text { Experience } \\
\text { of being a }\end{array}$ & & \\
\hline Name & Age & fishermen & Area of catching & State \\
\hline Albert & 50 years & 30 years & Coastal area & Johor \\
\hline Bryan & 43 years & 20 years & Coastal area & Terengganu \\
\hline Chris & 47 years & 29 years & Deep sea & Pahang \\
\hline Michael & 61 years & 43 years & Deep sea & Kelantan \\
\hline
\end{tabular}

Table 2: Fisheries districts in the east coast zone of Peninsular Malaysia

\begin{tabular}{ll}
\hline States & Fisheries districts \\
\hline Kelantan & Tumpat \\
& Kota Bharu \\
& Bachok \\
Terengganu & Pasir Puteh \\
& Besut \\
& Setiu \\
& North Kuala Terengganu \\
& South Kuala Terengganu \\
& Marang \\
& Dungun \\
Pahang & Kemaman \\
& Kuantan \\
Johor (East) & Pekan \\
& Rompin \\
& Mersing \\
& North Kota Tinggi \\
& South Kota Tinggi
\end{tabular}

Source: Department of Fisheries Malaysia

Table 3: Number of registered fishermen in the east coast zone of Peninsular Malaysia

\begin{tabular}{lr}
\hline $\begin{array}{l}\text { registered } \\
\text { States/Districts }\end{array}$ & $\begin{array}{l}\text { Number of } \\
\text { fishermen }(2009)\end{array}$ \\
\hline Kelantan & 6430 \\
Bachok and Pasir Puteh & 1744 \\
Kota Bharu & 1450 \\
Total & 9624 \\
Terengganu & \\
Besut & 2356 \\
South Kuala Terengganu & 2135 \\
Kemaman & 1874 \\
Marang & 1224 \\
Dungun & 1196 \\
North Kuala Terengganu & 876 \\
Setiu & 760 \\
Total & 10421 \\
Pahang & \\
Kuantan & 3720 \\
Rompin & 1987 \\
Pekan & 1317 \\
Total & 7024 \\
Johor (East) & \\
Mersing & 3041 \\
South Kota Tinggi & 1321 \\
North Kota Tinggi & 1134 \\
Total & 5496 \\
Overall total & 32565 \\
\hline Source:Department of Fisheries Malaysin
\end{tabular}


Am. J. Environ. Sci., 7 (5): 448-455, 2011

Table 4: Number of registered vessels in the east coast zone of Peninsular Malaysia

\begin{tabular}{lr}
\hline States/Districts & $\begin{array}{c}\text { Number of registered } \\
\text { vessels (2009) }\end{array}$ \\
\hline Kelantan & 702 \\
Tumpat & 700 \\
Bachok and Pasir Puteh & 518 \\
Kota Bharu & 1920 \\
Total & \\
Terengganu & 564 \\
Kemaman & 489 \\
Dungun & 481 \\
North Kuala Terengganu & 430 \\
Marang & 401 \\
Besut & 309 \\
South Kuala Terengganu & 232 \\
Setiu & 2906 \\
Total & \\
Pahang & 873 \\
Kuantan & 703 \\
Pekan & 417 \\
Rompin & 1993 \\
Total & \\
Johor (East) & 621 \\
South Kota Tinggi & 586 \\
Mersing & 317 \\
North Kota Tinggi & 1524 \\
Total & 8343 \\
Overall total &
\end{tabular}

Table 5: Productivity of fish landed per registered fishermen

\begin{tabular}{llll}
\hline Year & $\begin{array}{l}\text { Number of } \\
\text { registered } \\
\text { fishermen }\end{array}$ & $\begin{array}{l}\text { Total of marine } \\
\text { fish landed (in } \\
\text { tons) }\end{array}$ & $\begin{array}{l}\text { Average of marine } \\
\text { fish landed per } \\
\text { registered fishermen } \\
\text { (in tons) }\end{array}$ \\
\hline & & & \\
2005 & 24,163 & 318,642 & 13.187 \\
2006 & 26,168 & 386,263 & 14.760 \\
2007 & 25,901 & 336,099 & 12.976 \\
2008 & 29,860 & 361,578 & 12.109 \\
2009 & 32,565 & 334,864 & 10.283 \\
\hline
\end{tabular}

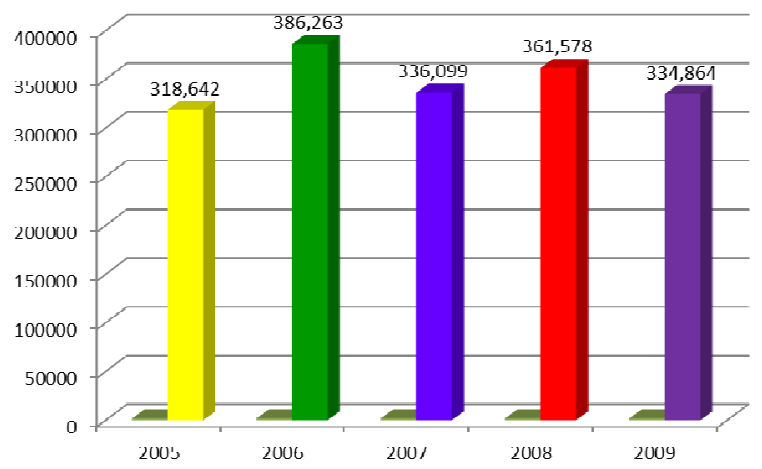

Source: Department of Fisheries Malaysia

Fig. 1: The productivity of Fishermen in the east coast zone of Peninsular Malaysia

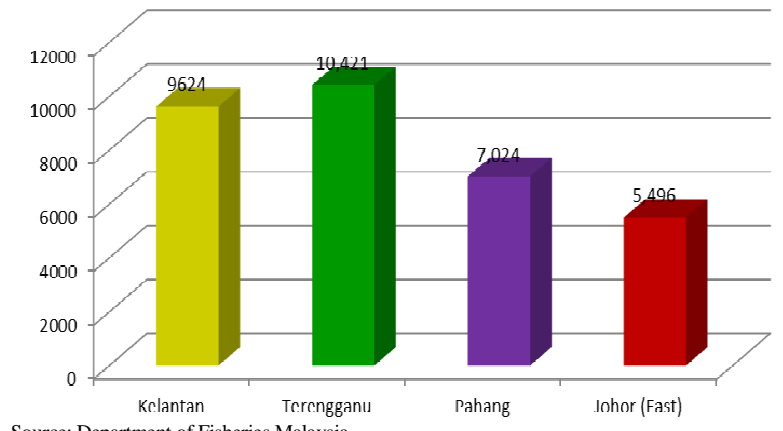

Source: Department of Fisheries Malaysia

Fig. 2: Number of registered fishermen in the east coast zone of Peninsular Malaysia

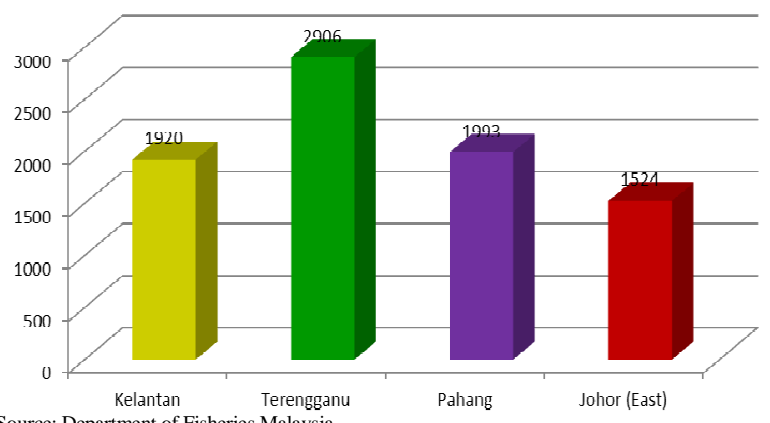

Source: Department of Fisheries Malaysia

Fig. 3: Number of registered vessels in the east coast zone of Peninsular Malaysia

Table 4 and Fig. 3 portray information regarding registered vessels in the east coast zone of Peninsular Malaysia. There are encouraging number of registered vessels in this zone where a total of 8343 vessel are registered. This number brings us to a probability that a higher productivity of the sea can be gained based on the highest number of registered vessels. Terengganu is the state with the highest number of registered vessel (2906), followed by Pahang (1993), Kelantan (1920) and East Johor (1524). Kuantan is the district with the highest number of registered vessels (873), followed by Pekan (703) and Tumpat (702). Not too many registered vessels can be found at the district of Setiu (232).

Has the sea changed? What are the possible factors that contribute to it: Climate change-global warming: Sea and coastal areas are among the major victims of the global warming phenomena and this indeed brings concern to us. The warmer world caused by global warming is predicted to further raise sea level by expending ocean water. The International Panel on Climate Change (IPCC) estimates that the global 
average sea level will rise between 0.6 and 2 feet $(0.18$ 0.59 meters) in the next century (Parry et al., 2007) Raising sea level increase the salinity of both surface water and ground water through salt water intrusion. If sea level rise pushes salty water upstream, then the existing water intakes might draw on salty water during dry periods. Salinity increases in estuaries also can harm sea fauna which are not suitable to live at the high salinity area. On top of it, the negative impact of the global warming also will affect cold and cool water species in low latitudes where extinction is likely to increase and biodiversity will decline. Doubtlessly, this will affect the quantity and quality of the marine fauna. On top of it, global warming can extinguish the coral reef through three ways. First, ocean warming is directly reducing coral cover through coral bleaching. Second, ocean warming can indirectly kill corals by magnifying the effects of infectious diseases and third is the climate change are causing the world ocean become more acidic which will bring more harms to the coral reef (Bruno, 2010). The stability of the sea current can be influenced by global warming. Scientist claimed that the sea water flow will be slowed by the global warming and as a result of these some part of the world will be cooler or less warm as the rest of the globe swelters (Bazilchuk, 2009).

Bottom trawling: Bottom trawling is among the main threat for the sea. This technique involves dragging huge, heavy nets along the sea floor. Large metal plates and rubber wheels attached to these nets move along the bottom and crush nearly everything in their path. As a result, entire marine life habitats are deposited into the nets, while only about $50 \%$ is target catch, the rest are wasted. On top of it, this technique brings a huge damage to the flora and fauna which includes coral reef, sea mounts, bottom dweller and others. This is not good as the flora and fauna in the deep water are very slow to recover from such damage, they indeed need decades to hundreds of years to recover; if they are able to do so.

Bottom trawling will cause our ocean to loss its abilities to produce protein for human. Not only that, they will also have less power to resist diseases and to act as the filter pollutants. It is alleged that one third of the sea species have been wiped out by bottom trawling. It is concern to us when some of the scientists are claiming that we could run out of seafood in fifty years due to this destructive fishing practice Gulf Coast Preservation Society.

Fishing pressure: Fishing pressure happens when fish and other marine fish are caught rapidly than their reproduced pace. One of the main causes that contribute to this is the increasing demand for seafood. Making thing worst is the poor management of fisheries and the emergence of new and more effective fishing methods. Usages of ICT such as GPS and sonar have the possibilities to contribute to the fishing pressure problem. This problem should be solved instantly, if this problem left uncheck, the marine ecosystem will extinguish and it will alter the stability of food security of majority of people in the world whom rely on the marine sources as their source of protein. Worm et al. (2006) have revealed that $75 \%$ of the world fish stocks are being harvested faster than they can reproduce. It is alarming situation when it was revealed that $80 \%$ of the world fish have been already full exploited or reduced in its quantity. There is probability that if this trend is persists, the world food fisheries could collapse entirely by 2050 . Table 5 clarifies the impact of the fishing pressure on the fisheries productivity in Malaysia. Based on the statistic provided by DOF, the number of registered fishermen in the east coast zone of Peninsular Malaysia is keep increasing year by year, but not on the productivity. The average of marine fish landed per registered fishermen was keep declining started from 2005-2009. It is a big concern to us that in 2009, the average of the marine fish landed per registered fishermen in this zone was the lowest (10.283 tones per registered fishermen). With the increasing number of registered fishermen, the productivity is predicted to increase, however that is not happening and fishing pressure can be one of the causes that might contribute to this.

\section{MATERIALS AND METHODS}

Methodology: The research approach for this study was a qualitative case study that provided an in-depth description on the perception of the fishermen on the current situation of the South China Sea and their perception on the potential impacts of these changes on their socio-economic activities. Data was collected by conducting four in-depth interviews among the registered fishermen guided by an interview guide. The questions served as a guide, but allowed respondents freedom and flexibility in their answers. For the purpose of secrecy, the respondents name appeared in this study are not their real name. The research employed a phenomenology approach. Data gained were transcribed verbatim and analyzed later. To further analyze the data, thematic analysis were used. The findings were in descriptive analysis. Questions pertaining to objective number 3 consumed the longest time and were discussed intensely. Questions that were asked to the respondents for the in-depth interview were designed to achieve the objectives of this study which are: 
- To discuss the perception of the east coast zone fishermen in Peninsular Malaysia on the current situation of the environment in the South China Sea (in term of water current, coastal areas, wind, wave. Temperatures and etc)

- To discuss the perception of the east coast zone fishermen in Peninsular Malaysia on any changes that has occurred in term of the quality and quantity of South China Sea fauna

- To identify the perception of the east coast zone fishermen in Peninsular Malaysia on the possible factors that contributes to these changes

- To reveal whether these changes have affected their socio-economic activities

\section{RESULTS}

Objectives 1: Discuss the perception of the east coast zone fishermen in Peninsular Malaysia on the current situation of the environment in the South China Sea (in term of whether, sea current, wind, waves and etc): From the data analyzed, it can be seen that all of the respondents studied have agreed that the situation of the South China Sea nowadays have changed a lot compared to the early days they started to become a fisherman. The fishermen interviewed have told us about the situation of the sea nowadays.

"Too strong, the wind is very strong indeed and it can broke the anchor rope, situation become worst if the rope used is not the good quality rope, it can be easily broken"Albert

The sea current is not stabile, sometimes it can be towards the south and suddenly it can change towards the east, it is hard nowadays." Chris

The waves are too turbulent nowadays; those with the small boat cannot go out there (sea) is too dangerous..."Michael

The fisherman has complaint on the difficulties to predict the weather nowadays compared to the early days as the fisherman

It is hard for us to predict the weather nowadays, let say we predict that today the weather should clear and it is ok for us to go out there (sea), but when we are on the sea, suddenly the weather changed and we do not know what to do"- Bryan.

Objective 2: To know the perception of the east coast zone fishermen in Peninsular Malaysia on any changes that has occurred in term of the south china sea fauna quality and quantity: When they were asked about the quality and the quantity of the sea flora and fauna, it seems that this is one of the questions that they like to talk about. It can be seen based on the interview that the quantity of the sea fauna has reduced a lot and the fishermen have confirmed this by stating:

The size is getting smaller nowadays, the smaller fish are more than the bigger fish, there are only few big fish out there, in the past there were a lot (big fish) but not nowadays"- Albert

Too few cuttlefish that have been caught this year, for this year activity (cuttlefish catching) is not as lively as last year, there are not too many cuttlefish for this year."Michael.

Last year we managed to catch almost 1015 kilos of cuttlefish each time we went out to the sea, but this year to get that number is too difficult"- Bryan

It is interesting to discover that one of the fishermen told us that he realized that the numbers of coral reef in his catching area have been reduced significantly stating:

Higher temperature can destroy the coral reef, when there is reduction in term of the number of coral reef; it will affect the fish productivity as carol reef is one of the habitats for the fish"-Bryan

Objective 3: To identify the perception of the east coast zone fishermen in Malaysia on the possible factors that contributes to these changes: Based on the interviews conducted it can be concluded that there are four factors which fishermen perceived to be the causes of the current situation nowadays; 1) illegal bottom trawling activities; 2) foreign fishermen intrusion; 3) the climate changes and 4) fishing pressure. All of these factors are among identified factors and the interviewed fishermen have confirmed this by stating:

Bottom trawling can be our main enemy, all of the things on the bottom of the sea, small fish, big fish; all are captured"-Michael

The main problem for us is the bottom trawling, small fish and small cuttlefish all deposited in the net. It can cause a huge damage on the ocean ecosystem, all are captured, small or big fish, that's why the 
number of fish nowadays are not as much as our early days as a fisherman, the small fisherman like me is facing big problem with this"- Chris

We have four zones of fish catching activities, zone a, zone b, zone $\mathrm{c} 0$ and zone c2. Each of the registered vessels are allowed to catch fish at their own zone and not allowed to enter other fishing zone. For example, vessels of zone c2 cannot enter zone $b$ fishing area because it is allocated for the smaller boat, but some of them when they know that there are lot of fish on that zone, they just catch fish on the zone regardless of their catchment zone, this can cause fishing pressure"- Bryan

There is a number of boats out there (foreign fishermen intrusions), they catch fish on our area and actions must be taken"- Albert

We can consider the impact (global warming) on the South China Sea can be mild, however the impact is increasing day by day and caused difficulties to us"-Bryan

Objective 4: To reveal whether these changes has affected their socio-economic activities: In term of impacts on their socio-economic activities, they all agreed that the environmental changes on the South China Sea have caused some of their socio-economic activities to be cancelled. Respondents have clarified on this by stating:

"It has reduced (their catching), the heavy rain has hindered us from going out to the sea, even though during that time(heavy rain) tons of fish can be landed, but if there are heavy rain on the sea, we need to cancel any activities"- Albert

Besides rain, the stability of the sea current is also important factor to be considered by the fishermen to go out to the sea to do their routine, one of the respondents has stated,

"Recently, not too many fishermen can go out to the sea due to the instability of the sea current, fishermen that using the purse seine like me heavily depend on the sea current, if the current is not good, then I cannot catch the fish" -Chris

One of the respondents has claimed that the impact of global warming has given him a problem in term of his income stability and he also claimed that the other activities that generate additional income for the fishermen are also are inhibited by saying:

\begin{abstract}
"Yes, we can feel the impact (global warming), we cannot go out to the sea and now our income has reduced. There are also fishermen affected by the climate nowadays because some of them are running agrotourism business. Sometimes, some of the anglers need to cancel their fishing trip due to the bad climate" -Bryan
\end{abstract}

Not only weather nowadays is affecting their economic activities, but it also has caused them to reduce their family socio activities such as fishing, netting and filling their leisure time. They stated that:

If there is any heavy rain, strong wind and the environment is too hot, it is better for us to stay at home rather than for us to go outside (to do social activities such as fishing, netting and filling their leisure time)"-Michael

"It is too hot out there, it is better for us to stay at our home, even if we switch on the fan, it is still hot"-Michael

\section{DISCUSSION}

The current situation of the sea as been perceived by the east coast fishermen in Peninsular Malaysia is not a new phenomenon; Countries all around the world are experiencing the same problem. Changes in the temperature for example have been studied widely. Alexander et al. (2006), stated that between 1951 and 2003 the world has indicated a significant increase in the annual warm nights while the occurrence of cold night indicated a similar proportion of significance decrease. Simamora 2011 in his report has stressed that some of the fishermen could not anymore rely on their instinct to predict the weather due to unpredictable weather condition nowadays.

Based on the data gained, the fishermen perceived that the impact of global warming can already be seen. This is not surprising as a number of local studies in Malaysia have proved it. Based on what has been done by Wai et al (2005), temperature of east coast zone of Peninsular Malaysia has indicated an increase of $2.90^{\circ} \mathrm{C}$ in the past 30 years (1971-2001). On the other hand has stressed that impacts of global warming can be clearly seen when the flood strike us on 2006 where states such as Johor, Kedah and Kelantan have suffered from this disaster.

In this study, factors such as bottom trawling, foreign fisher intrusion, climate change and fishing 
pressure are the main factors contributing to the changes environment. This is not surprising as there are abundance studies done by scientist, government and NGOs are consistent with the finding of thia study. Bottom trawling has been mention as one of the main contributors for the changes that happens. Acting as bulldozer on the sea, it will capture all things in its way. Research done by Gulf Coast Preservation Society, has revealed that if the bottom trawling is still used as a technique to catch fish, it is predicted that world will be running short of fish supply in the next 50 years and Malaysia can be one of the potential victims of this problem.

This study revealed that the changes that occurred nowadays have indeed reducing the socio-economic activities of the fishermen. The number of days spend on the sea has reduced and this will have negative impact on their income. Findings from Simamora 2011 has agreed with this finding. The warmer ocean and the instability of the sea current will have impact on the fish habitat. It is a bit concern as study by Ngingo (2010) and Bazilchuk (2009) has concluded that a warmer world do have influence on fish productivity and other marine species. Some of the marine species cannot tolerate warmer temperature and changes on the sea current and many migrate to other part of the sea, this means that fishermen need to seek a new area for their new fishing activities and this involves more consumption of the fuel, their time and energy. It was also found that due to bad and unpredictable weather, some of the recreational activities which generate additional income for the fishermen need to be cancelled.

Based on the data gained, there are number of recommendations suggested to further increase the productivity of fishermen of east coast zone in Malaysia:

- More monitoring activities/action the related agencies on the use of bottom trawling among the local fishermen

- Effective program such as "**Rakan Cop" which is introduced by the Royal Police of Malaysia (launched by Royal Malaysian Police in Kuala Lumpur on August 9, 2005 to help combat crime in the city and the situation around Malaysia) can also be practiced among the fishermen and the related agencies. By doing this, if there is any intrusion by the foreign fishermen detected, the local fishermen can communicate with related agencies and immediate actions can be taken.

- Awareness campaign on the damages brought by the bottom trawling for today and the future of the marine lives
- Fishing quotas can be one of the mechanisms to overcome fishing pressure problems. On top of it, fishing suspension on some area on selected period of each year (China and Japan have practiced this) also can be one of the mechanisms

- There is a need for information dissemination of the global warming effect on the socio-economic activities of the fishermen, for this purpose, mass media such as print media (ex: Newsstudy, brochure and pamphlet), electronic media (television and radio) and the internet can be the effective mediums

- Awareness campaign among the fishermen on how they can save the world by lesser energy consumption should be conducted.

\section{CONCLUSION}

Based on the data gained, it can be concluded that the fishermen interviewed agreed that the current situation of the sea are not the same compared to their early days as a fishermen. The sea current, waves and weather for example are not stable and cannot easily predict by them. Not only the sea environment has changed, they also realized that there are significant changes in term of sea flora and fauna. The size quantity and quality of the sea fauna have changed; the fish are smaller in term of their size and quantity while they also claimed that the number of coral reef in their catching area has reduced. In their opinion, there are four factors that can contribute to these changes which are: (1) bottom trawling activities; (2) the climate change; (3) foreign fishermen intrusion and 4) fishing pressure.

On top of it, the fishermen also claimed that the changes have brought negative impacts to their socioeconomic activities such as decreases in the number of the days they can go out to the sea, decreases in their productivities, increase risks and inhibit their social activities.

\section{REFERENCES}

Alexander, L.V., X. Zhang, T.C. Peterson, J. Caesar and B. Gleason et al., 2006. Global observed changes in daily climate extremes of temperature and precipitation. J. Geophys. Res., 111: 1-22. DOI:10.1029/2005JD006290

Bazilchuk, N., 2009. In deep water: Will essential ocean currents be altered by climate change? Scientific American, a Division of Nature America, Inc. 
Bruno, J., 2010. Coral reefs and climate change. The Encyclopedia of Earth.

D'Silva, J.L., B.A. Samah, H.A.M. Shaffril and N. Man, 2011. Preservation of the environment through sustainable agriculture practices: A case study on the attitude of crop farmers. Am. J. Environ. $\quad$ Sci., $\quad 7$ : 195-199. DOI: 10.3844/ajessp.2011.195.199

Fuller, A.C. and M.O. Harhay, 2010. Population growth, climate change and water scarcity in the southwestern United States. Am. J. Environ. Sci., 6: 249-252. DOI: 10.3844/ajessp.2010.249.252

Hamdi, M.R., M. Abu-Allaban, A. Al-Shayeb, M. Jaber and N.M. Normani, 2009. Climate change in jordan: A comprehensive examination approach. Am. J. Environ. Sci., 5: 58-68. DOI: 10.3844/ajessp.2009.58.68

Mia, M.S., R.A. Begum, A.C. Er, R.D.Z.R.Z. Abidin and J.J. Perreira, 2011. Malaria and climate change: Discussion on economic impacts. Am. J. Environ. Sci., 7: 65-74. DOI: 10.3844/ajessp.2011.73.82

Ngingo, E., 2010. Warming lake leaves Tanzanian fishing families short of money, food. University of British Columbia, Canada.

Parry, M.L., 2007. Climate Change 2007: Impacts, Adaptation and Vulnerability: Contribution of Working Group Ii to the Fourth Assessment Report Of The Intergovernmental Panel On Climate Change. 1st Edn., Cambridge University Press, Geneva, ISBN-10: 0521880106, pp: 976.
Rashid, M., J.J. Pereira, R.A. Begum, S. Aziz and M.B. Mokhtar, 2011. Climate change and its implications to national security. Am. J. Environ. Sci., 7: 150160. DOI: 10.3844/ajessp.2011.150.160

D'Silva, B.A.S.J.L., H.A.M. Shaffril and J. Uli, 2010. Attitude towards contract farming among malaysian agriculture learning institution students. Am. J. Econ. Bus. Admin, 2: 266-271. DOI: 10.3844/ajebasp.2010.266.271

Shaffril, H.A.M., J.L. D'Silva, J. Uli and B.A. Samah, 2010. Gender Issue in contract farming: the case of malaysian students. Am. J. Agric. Biol. Sci., 5: 204209. DOI: 10.3844/ajabssp.2010.204.209

Uli, J., J.L. D'Silva, H.A.M. Shaffril and B.A. Samah, 2010. The attitude, belief, support and knowledge level of the youth and their acceptance towards agriculture contract farming. J. Soc. Sci., 6: 350355. DOI: $10.3844 /$ jssp.2010.350.355

Wai, N.M., A. Carmelengo and A.W.A. Khairi., 2005. A Study of Global Warming in Malaysia. J. Teknol., 42: 1-10.

Worm, B., E.B. Barier, N. Beaumont, J.E. Duffy and C. Folke et al., B.S. 2006. Impacts of biodiversity loss on ocean ecosystem services. Science, 314: 787790. DOI: $10.1126 /$ science. 1132294 